\title{
Spatial Distribution of Dengue Hemorrhagic Fever (DHF) Casesin Sragen
}

\author{
Dodiet Aditya Setyawan*, Wiwik Setyaningsih \\ Politeknik Kesehatan Kementerian Kesehatan Surakarta, Central Java, Indonesia \\ *corresponding author, e-mail: aditya.12st@gmail.com \\ Received:11/05/2020; published:01/04/2021
}

\begin{abstract}
Background: Dengue Hemorrhagic Fever (DHF) had still become a health problem that often occurred and not least caused death for Indonesia especially in Sragen, Central Java. Distribution of DHF cases in an area could be described using Spatial analysis with Geographic Information Systems (GIS). Objective: This study aimed to provide spatial distribution of Dengue Hemorrhagic Fever cases and regional endemicity of DHF in Sragen during 2016-2018 using Geographic Information Systems. Method: Descriptive research design with Cross-Sectional approach using GIS was used to get the description of spatial distribution of dengue and the region endemicity of dengue in Sragen. The sample used was Saturated Sample which was secondary data about the incidence of DHF from District Health Office of Sragen from 2016 to 2018 totaling 1,349 cases. The subjects consisted of geographical areas which consisted of 20 subdistricts with DHF case. The collected data were analyzed descriptively by displaying a frequency distribution table and description of spatial distribution using Geographic Information System. Results: The results showed that the spatial distribution of DHF was spread randomly in all districts in Sragen. The average incidence rate (IR) of DHF during the last 3 years in Sragen was $>50 / 100,000$ population. Spatial description showed that 58 villages out of 208 villages in Sragen were DFH endemic areas and generally all subdistricts in Sragen were endemic areas of DHF. Conclusion: Spatial description of DHF in Sragen showed that all subdistricts in Sragen were endemic areas for DHF.
\end{abstract}

Keywords: Dengue Hemorrhagic Fever (DHF); spatial distribution; DHF endemicity; Geographic Information Systems (GIS)

\section{Copyright $@ 2013$ Universitas Ahmad Dahlan. All rights reserved.}

\section{Introduction}

Diseases related to environmental conditions are still a common health problem and have caused many deaths in Indonesia. This can be seen from the high number of visits of sufferers of these diseases, in which one of them is Dengue Hemorrhagic Fever (DHF), to health service centers [1]. According to the World Health Organization (WHO), the highest incidences of DHFare in the West Pacific region, Southeast Asia and several countries in America.The number of dengue cases was reported to be 3 million cases in 2015; and in 2016 there were reported dengue outbreaks in several countries in the world. Meanwhile, Indonesia is the country that has the highest number of DHF cases in Asia [2].

In 2017, the number of DHF cases in Indonesia was recorded at 68,407 cases, where the highest number of cases occurred in Java and Central Java was in the 3rd place with 7,400 cases and was the second National Province with the highest death rate in Indonesia due to DHF, with the highest number as many as 92 deaths [3]. Sragen is an area that is not yet free ofthis disease [4]. Data from the Central Java Health Profile in 2018 shows that Sragen ranks 3rd as the District with the highest DHF Incidence Rate (IR) in Central Java, which is 35.59 per 100,000 population [5].

The Geographic Information System (GIS) is able to provide information that has geographic references and can show an overview of the spatial distribution of DHF cases in 
an area and the trend of the spread of the disease [6]. Data from the Sragen Health Office shows that in the last 3 years i.e., 2016-2018, the incidence of dengue cases was 1,349 cases spread across all subdistricts in Sragen. The description of the distribution of DHF cases can be described more clearly through GIS. Besides, with this GIS, an overview of the areas that have DHF cases will be obtained each year.Therefore, this study aimed to provide an overview of the spatial distribution of DHF cases and to identify the regional endemicity of DHF in Sragen. By knowing the spatial distribution of DHF cases, steps to prevent and control the incidence of DHF in an area can be faster and more precise, so as to prevent Extraordinary Events or Kejadian Luar Biasa (KLB).

\section{Method}

This research was a descriptive study with a cross sectional approach using a Geographic Information System (GIS) to obtain an overview of the spatial distribution of cases of Dengue Hemorrhagic Fever (DHF) in Sragen [7]. The data used were secondary data about the incidence rate of DHF from the Sragen Health Office 2016-2018 and population density from Statistics Indonesia of Sragen in 2016-2018 [8]. Data on the number of DHF cases studied were all the incidence rates of DHF during the last 3 years which were expected to provide an overview of the endemicity of an area, which is a subdistrict, on the incidence of DHF. Subdistricts which were endemic to DHF were subdistricts in which there were dengue fever sufferers each year in last three years [9]. This study only described the number of DHF cases and their distribution in each area in Sragen and did not show the coordinates of the location of DHF sufferers. The subjects in this study were the incidences of DHF in Sragen in 2016-2018. The sampling technique in this study was saturated samples, that is, all cases of DHF in 2016-2018 in order to provide a true picture of the incidence of DHF in Sragen in the last 3 years. The data collected in this study would then be analyzed descriptively by displaying a frequency distribution table. Meanwhile, the description of the spatial distribution of DHF cases usedthe Geographic Information System using the overlay function $[10,11]$. Data analysis was performed using QGIS software.

\section{Results and Discussion}

3.1 Result

3.1.1 Description of Dengue Hemorrhagic Fever (DHF) Case Distribution and Population Density in 2016-2018

Distribution of DHF cases and population density in Sragen in 2016-2018 illustrates that in thoseyears there were DHF cases in all subdistricts. The number of DHF incidence rates was different every year, but had a tendency to decrease in that time period. Meanwhile, the population density in Sragen during those last 3 years had always increased. More details are presented in Table 1.

Table 1.Distribution of Frequency Number of DHF Cases and Population Density (PpD) in Sragen 2016-2018

\begin{tabular}{lcccccc}
\hline \multirow{2}{*}{ Subdistricts } & \multicolumn{2}{c}{ 2016 } & \multicolumn{2}{c}{2017} & \multicolumn{2}{c}{2018} \\
\cline { 2 - 7 } & DHF & PpD & DBD & PpD' & DHF & PpD $^{\prime}$ \\
\hline Jenar & 28 & 419 & 6 & 420 & 13 & 422 \\
Tangen & 10 & 471 & 11 & 472 & 21 & 473 \\
Miri & 46 & 603 & 4 & 604 & 23 & 605 \\
Sukodono & 37 & 648 & 4 & 649 & 11 & 651 \\
Sumberlawang & 45 & 588 & 6 & 588 & 38 & 589 \\
Mondokan & 48 & 686 & 4 & 687 & 20 & 688 \\
Gesi & 7 & 501 & 1 & 502 & 16 & 503 \\
Ngrampal & 24 & 1.088 & 2 & 1.089 & 9 & 1.091 \\
\hline
\end{tabular}




\begin{tabular}{lcccccc}
\hline \multirow{2}{*}{ Subdistricts } & \multicolumn{2}{c}{$\mathbf{2 0 1 6}$} & \multicolumn{2}{c}{$\mathbf{2 0 1 7}$} & \multicolumn{2}{c}{$\mathbf{2 0 1 8}$} \\
\cline { 2 - 7 } & DHF & PpD & DBD & PpD & DHF & PpD $^{\text {? }}$ \\
\hline Sambungmacan & 30 & 1.158 & 7 & 1.160 & 11 & 1.161 \\
Tanon & 94 & 1.008 & 6 & 1.009 & 31 & 1.010 \\
Sragen & 55 & 2.524 & 5 & 2.535 & 8 & 2.545 \\
Gemolong & 67 & 1.159 & 18 & 1.163 & 32 & 1.167 \\
Sidoharjo & 44 & 1.120 & 13 & 1.127 & 7 & 1.123 \\
Gondang & 30 & 1.022 & 5 & 1.023 & 11 & 1.025 \\
Kalijambe & 89 & 1.042 & 12 & 1.047 & 20 & 1.052 \\
Plupuh & 24 & 890 & 4 & 891 & 13 & 892 \\
Karangmalang & 34 & 1.551 & 12 & 1.566 & 16 & 1.583 \\
Masaran & 105 & 1.662 & 17 & 1.675 & 10 & 1.689 \\
Sambirejo & 18 & 737 & 5 & 738 & 2 & 739 \\
Kedawung & 34 & 1.191 & 6 & 1.197 & 22 & 1.203
\end{tabular}

\subsubsection{Spatial Description of DHF Case Distribution based on Population Density in} Sragen 2016-2018

The spatial description of the distribution of DHF cases based on population density in Sragen in 2016-2018 showed that DHF cases were distributed in all subdistricts in Sragen, eitherareas with population density levels whichwerelow, moderate, or high. Areas with low population density had DHF cases as many as areas with moderate and high population density levels. The point image on the map shows the distribution of the number of cases and does not show the coordinates of the actual cases.

The spatial distribution of the number of DHF cases in Figure 1-3 shows that the highest number of DHF cases in 2016 was 867, occurring in almost all subdistricts in Sragen, with the exception ofTangenSubdistrict and GesiSubdistrict with only 10 and 7 cases respectively. Then, in 2017 the incidence of DHF in all subdistricts showed a very drastic decrease in the number of cases. However, in 2018 the number of DHF cases increased again in all Districts in Sragen.

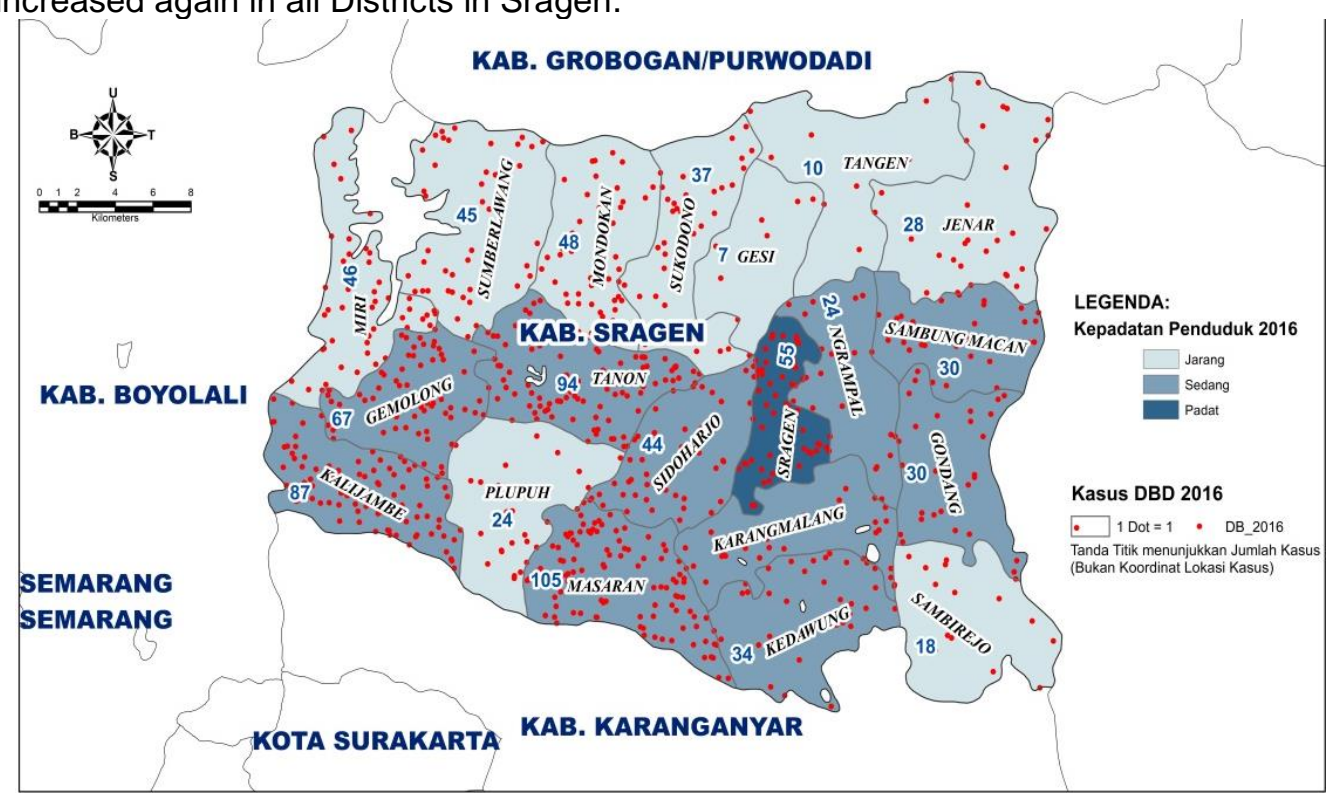

Figure 1. Map of Spatial Distribution of DHF Cases based on Population Density in Sragen in 2016

Disease Prevention and Public Health Journal

Volume 15, Issue 1, March 2021: $42 \sim 49$ 


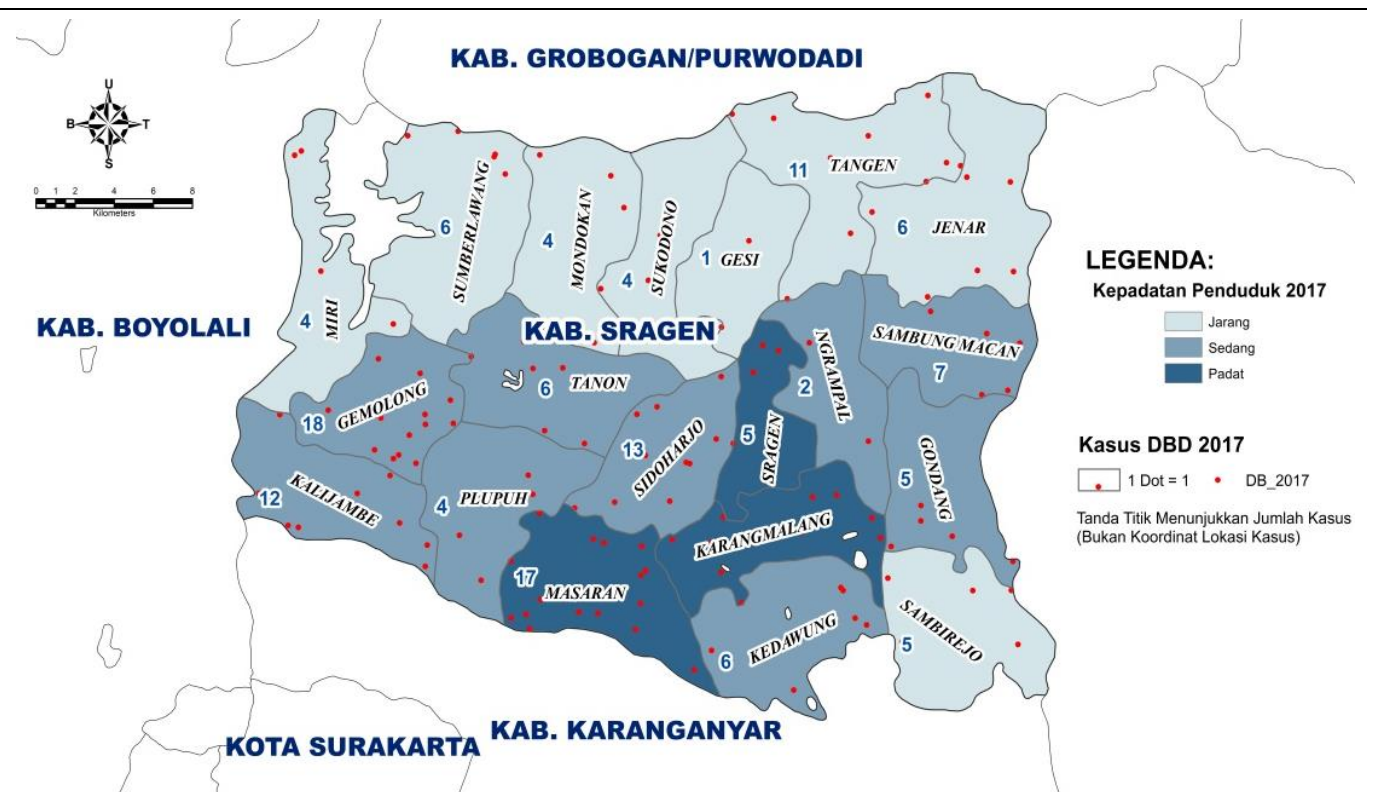

Figure 2. Map of Spatial Distribution of DHF Cases based on Population Density in Sragen in 2017

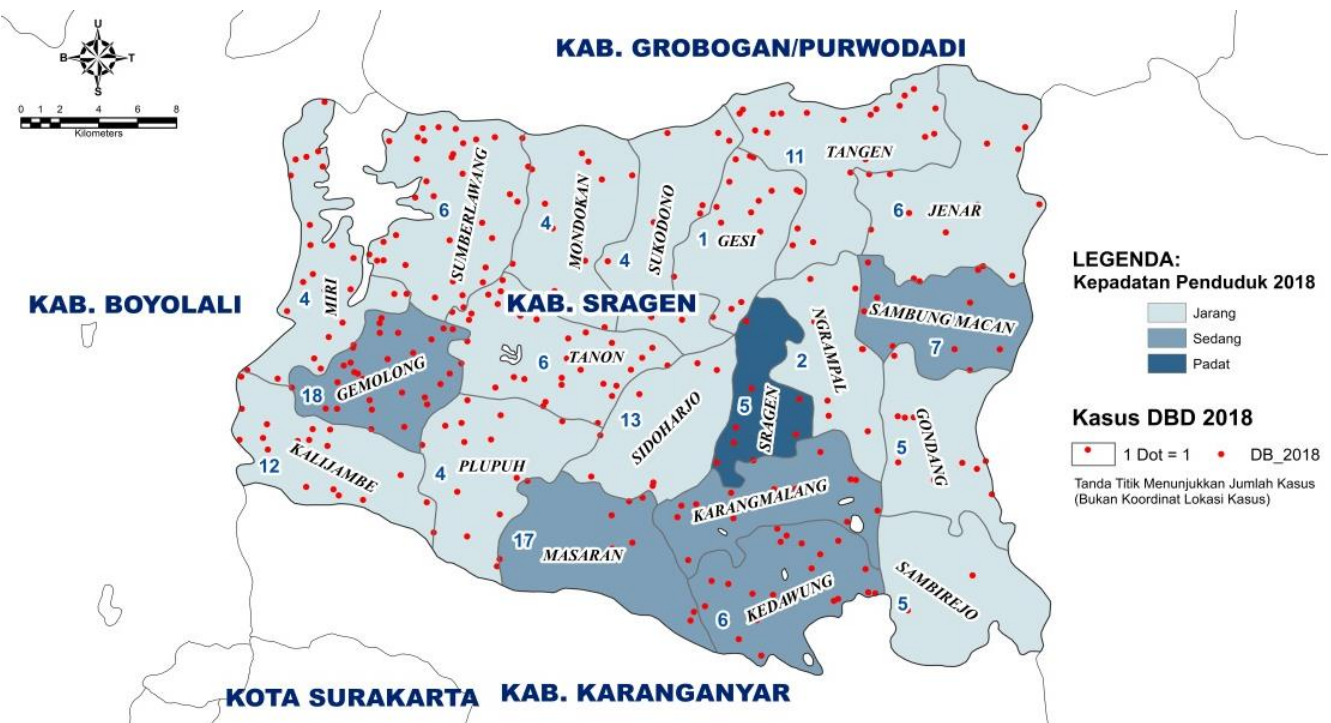

Figure 3. Map of Spatial Distribution of DHF Cases based on Population Density in Sragen in 2018

\subsubsection{Spatial Description of DHF Endemicity Stratification in Each Subdistrict in Sragen 2016-2018}

Endemicity stratification, or the stratification of DHF-prone areas, is differentiated into endemic, sporadic, potential and free area. An area is said to be endemic if there have been cases of DHF every year in the last 3 years. An area that has been infected with DHF within 3 years but not every year is included in the sporadic category. Whereas in areas where in the last 3 years there were no DHF sufferers, but had a dense population, had busy transportation links with other areas, and the percentage of houses found with larvae was more or equal to $5 \%$, then it is included in the potential criteria;and areas where there has never been a single DHF case in the last 3 years and the percentage of houses found with larvae is less than $5 \%$ are included in the criteria for a DHF free area [9]. 
The data depicted by the map in Figure 4 below shows that at the village/subsubdistrict level in Sragen, there were still many areas, a total of 58 , that were endemic to DHF. The sub-district areas with the greatest number of villages/sub-subdistricts whichwere endemic to DHF were in MasaranSubdistrict with 6 villages/sub-subdistricts, namely Sepat, Dawungan, Masaran, Jati, Pringanom and Krikilan Villages. And KarangmalangSubdistrict also had6 villages/sub-subdistricts, namely Kedungwaduk, Puro, Mojorejo, Pelemgadung, Plumbungan and Kroyo villages.

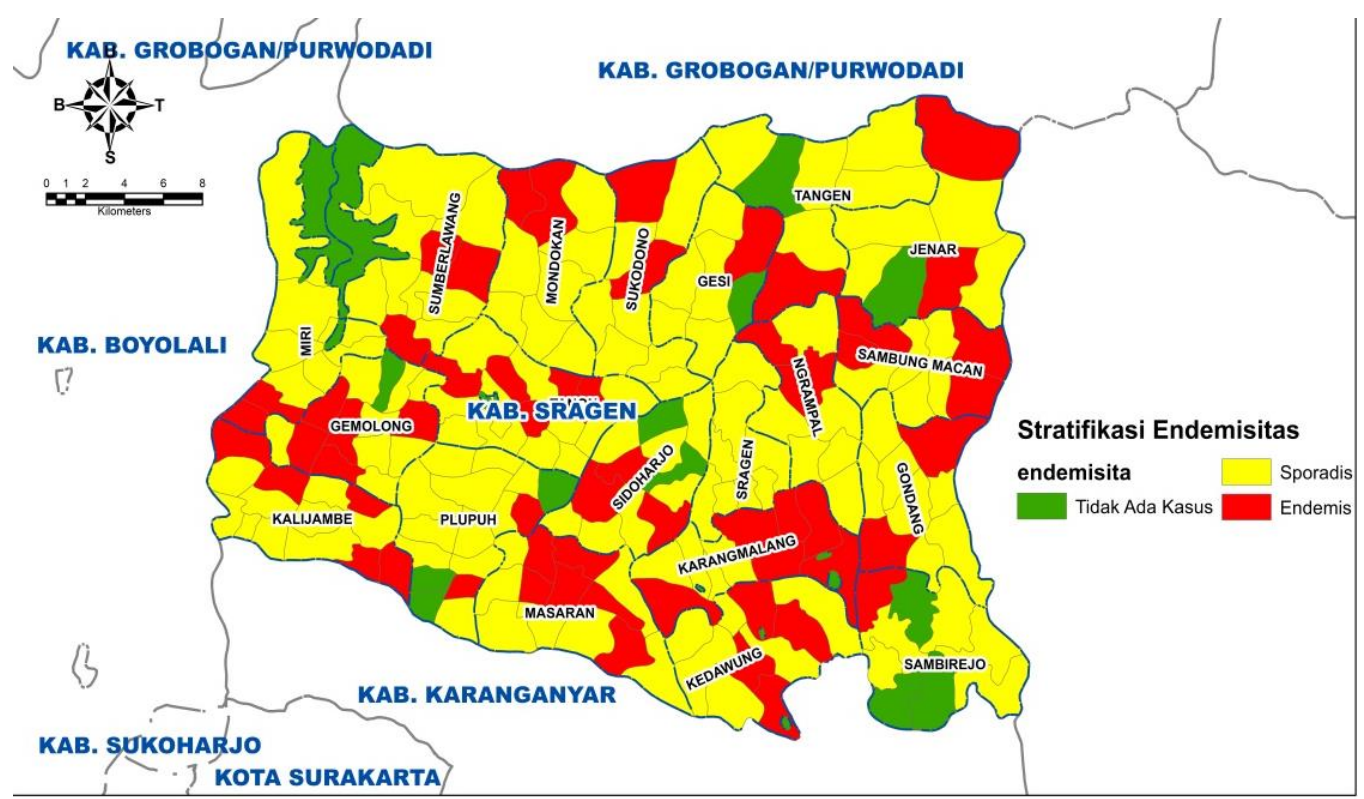

Figure 4. Map of Spatial Description of DHF Endemicity Stratification in Each Village/Sub-Subdistrict in Sragen 2016-2018

While at the sub-district level, the results of the spatial analysis of the incidence of DHF showed that all subdistricts in Sragenwere endemic areas for DHF. The spatial description of subdistrict endemicity was presented in Figure 5.

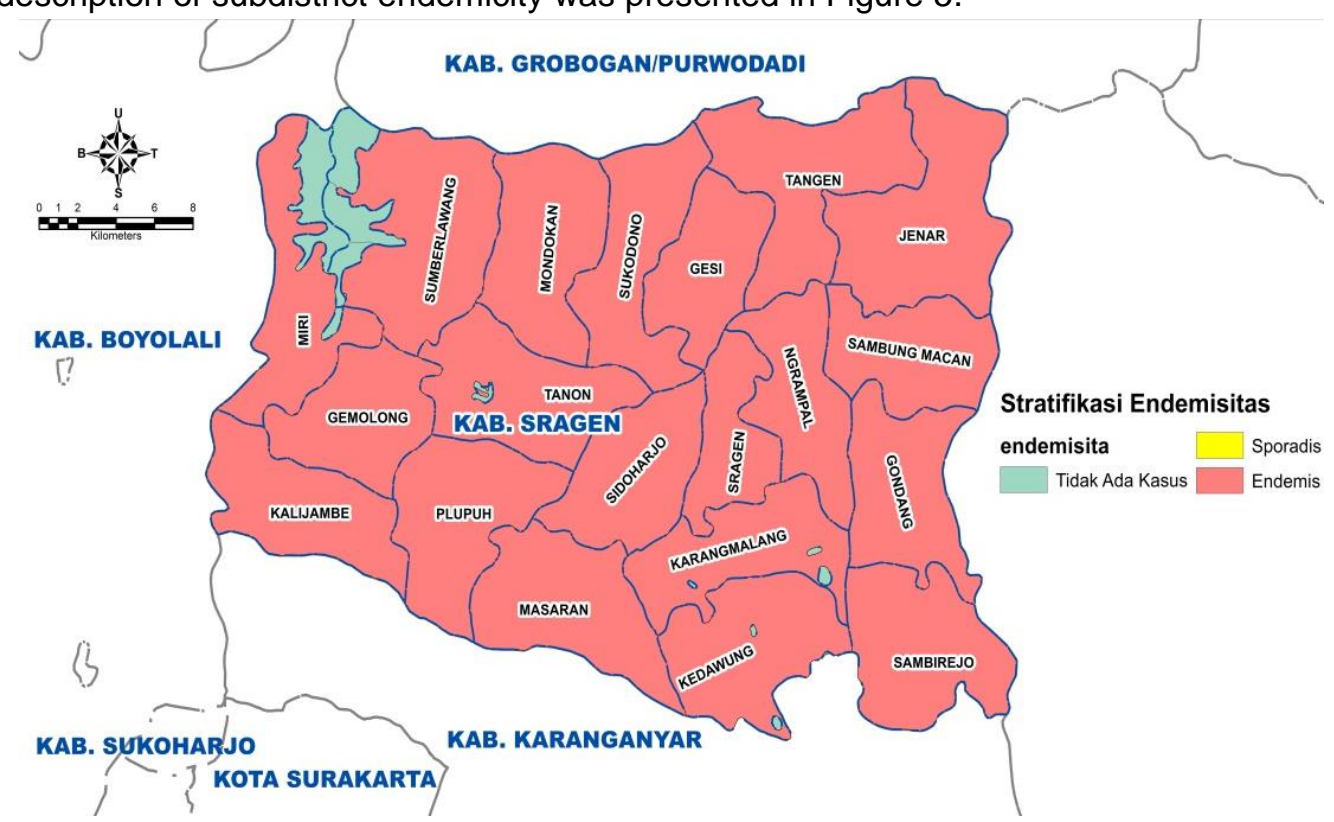

Figure 5. Map of Spatial Stratification of DHF Endemicity in Each Subdistrict in Sragen 2016-2018 


\subsection{Discussion}

The results of the mapping of the distribution of DHF incidences based on the population density in Sragen in 2016-2018 showed that the incidence of DHF in Sragen was distributed in all subdistricts. This study showed that between areas with high, moderate or low population density, DHF cases are equally found. This is because the distribution of the population in Sragen is very varied, where population density is not only found in one urban area, but also in several rural areas. The description of the results like this is consistent with the research which proves that there has been a shift in the incidence of DHF from urban to rural areas [12]. The DHF morbidity rate in Sragen had fluctuated from 2016-2018. The level of population density in Sragen is almost the same in each subdistrict; both rural and urban areas. It is possible that the influence of population density for the incidence of DHF becomes meaningless because the incidence of DHF cases in Sragen from 2016-2018 was distributed to all subdistricts in Sragen $[13,14]$.

The description of the spatial distribution of the number of DHF incidence rates in Sragen in 2016-2018 shows that the most incidences occurred in 2016. Whereas in 2017 there was a decrease in all subdistricts, but in 2018 the incidence of DHF in Sragen had again increased quite significantly. The increase in the number of DHF cases could be due to environmental conditions that support Aedes Agepty mosquitoes to breed well $[15,16]$. In addition, community behavior regarding the prevention and eradication of DHF needs to be improved so that the spread of DHF can be prevented $[17,18]$.

The distribution pattern of DHF cases in Sragen in 2016-2018 was distributed in all subdistricts. Sub-districts with significant increases were Miri, Sumberlawang, Tanon, Mondokan and Gesisubdistricts. Sub-district areas that have a situation like this can make an Extraordinary Events or Kejadian Luar Biasa (KLB) possible. The map of the spatial description of the incidence of DHF in Sragenin 2016-2018 showed that in 3 consecutive years all subdistricts in Sragen hadDHF cases with the incidence rates varying from low to high.

Based on the spatial description of DHF endemicity stratification in Sragen, out of 208 villages/sub-subdistricts, 58 were dengue endemic areas and only 12 were included in the category of dengue free areas;while 137 others are classified into the sporadic category[19,20]. Based on the description of the results, it can be seen that all districts in Sragen, a total of 20 subdistricts, were in the category of endemic areas for DHF. This study shows the same results as previous studies that there has been a shift in the incidence of DHF, which was originally more in urban areas, but then shifted to rural areas [21]. Furthermore, the level of population density also has a weak or no effect on the incidence of DHF [12-14,22,23].

The spatial description of the incidence of DHF in the subdistrict areas showed that all subdistricts in Sragen each year in the 2016-2018 period were still infected with DHF cases; so that all districts in Sragenwere endemic to DHF. The results of the study using a spatial picture like this in the end can provide clearer and more accurate information about the spatial distribution of DHF incidences and a picture of regional endemicity of DHF in all districts in Sragen.

\section{Conclusion}

The incidence of Dengue Hemorrhagic Fever (DHF) in Sragen Regency in 2016-2018 is still high with an average incidence rate of more than 50 per 100,000 population. From the spatial description, it shows that the incidences of dengue fever were spread across all subdistricts in Sragen and all subdistricts were endemic areas for DHF disease. Therefore, it is recommended to related agencies to always carry out surveillance activities for DHF 
disease in a more comprehensive manner, improve the role of the community in Mosquito Nest Eradication or Pemberantasan Sarang Nyamuk (PSN) activities, monitoring larvae in each region through more active health promotion and involving the participation of health cadres.

\section{References}

1. Kemenkes RI. Demam Berdarah Dengue di Indonesia Tahun 1968-2009.Bul Jendela Epidemiol. 2010;2.ISSN-2087-1546.

2. Syamsir S, Pangestuty DM. Autocorrelation of Spatial Based Dengue Hemorrhagic Fever Cases in Air Putih Area, Samarinda City. J Kesehat Lingkung. 2020;12(2):78-86.

3. Kementerian Kesehatan RI. Situasi Penyakit Demam Berdarah Dengue di Indonesia Tahun 2017. Infodatin. Jakata: Pusat Data dan Informasi Kemenkes RI; 2018.

4. Setyawan DA. Study Epidemiologi Dengan Pendekatan Analisis Spasial Temporal Pada Kejadian Demam Berdarah Dengue (DBD) di Kecamatan Masaran Kabupaten Sragen Tahun 2016-2018. Interes J IImu Kesehat. 2019;8(2):189-196.

5. Jateng DKP. Profil Kesehatan Provinsi Jawa Tengah Tahun 2018. Semarang: Dinas Kesehatan Propinsi Jawa tengah; 2019.

6. Hamer D, Lichtveld M. Spatial Distribution of Epidemiological Cases of Dengue Fever in Suriname, 2001-2012. West Indian Med J. 2015;64(4):344-350.

7. Prasetyo A, Rohmatun N. Implementasi Sistem Informasi Geografis dan Data Center untuk Pemetaan Penyebaran Penyakit Demam Berdarah di Kabupaten Ponorogo. Multitek Indones. 2015;9(1):9-10.

8. BPS Kabupaten Sragen. Kabupaten Sragen Dalam Angka 2018. Sragen, Jawa Tengah: BPS Kabupaten Sragen; 2019.

9. Direktorat Jenderal PP \& PL Kementerian Kesehatan RI. Modul Pengendalian Demam Berdarah Dengue. Darmawali Handoko, Endang Burni Prasetyowati SH, editor. Jakarta; 2011. $27 \mathrm{p}$.

10. Zambrano LI, Rodriguez E, Espinoza-Salvado IA, Fuentes-Barahona IC, Lyra de Oliveira $T$, Luciano da Veiga G, et al. Spatial distribution of dengue in Honduras during 20162019 using a geographic information systems (GIS)-Dengue epidemic implications for public health and travel medicine. Travel Med Infect Dis. 2019;32:101517.

11. Handayani S, Fannya P, Rosa SH, Inge Angelia. Analisis Spasial Temporal Hubungan Kepadatan Penduduk Dan Ketinggian Tempat Dengan Kejadian DBD Kota Padang. $J$ Kesehat Med Saintika. 2017;8(1):25-34.

12. Karyanti MR, Hadinegoro SR. Perubahan Epidemiologi Demam Berdarah Dengue Di Indonesia. Sari Pediatr. 2016;10(6):424-432.

13. Kaunang WPJ, Ottay RI. Pemetaan Penyebaran Penyakit Demam Berdarah Dengue Dengan Geographic Information System Di Minahasa Selatan. J Kedokt Komunitas dan Trop. 2015;3(2):90-98.

14. Pongsilurang CM, Sapulete MR, Kaunang WPJ. Pemetaan Kasus Demam Berdarah Dengue Di Kota Manado. J Kedokt Komunitas dan Trop. 2015;3(2):66-72.

15. Hii YL, Zaki RA, Aghamohammadi N, Rocklöv J. Research on Climate and Dengue in Malaysia: A Systematic Review. Curr Environ Heal Reports. 2016;3(1):81-90.

16. Akter R, Hu W, Naish S, Banu S, Tong $S$. Joint effects of climate variability and socioecological factors on dengue transmission: epidemiological evidence. Trop Med Int Heal. 2017;22(6):656-669.

17. Parulian Manalu HS, Munif A. Pengetahuan dan Perilaku Masyarakat dalam Pencegahan Demam Berdarah Dengue di Provinsi Jawa Barat dan Kalimantan Barat. ASPIRATOR - J Vector-borne Dis Stud. 2016;8(2):69-76.

18. Anggraini A. Pengaruh kondisi sanitasi lingkungan dan perilaku $3 \mathrm{M}$ plus terhadap kejadian demam berdarah dengue di Kecamatan Purwoharjo Kabupaten Banyuwangi. J Pendidik Geogr. 2016;3(3):321-328.

19. Sahrir N, Ishak H, Maidin A. Pemetaan karakteristik lingkungan dan densitas nyamuk Aedes aegypti berdasarkan status endemisitas DBD di Kecamatan Kolaka. JST Kesehat. 2016;6(1):70-75.

20. Khairiati L, Fakhriadi R. Analisis Perbedaan Faktor Risiko Kejadian Demam Berdarah Dengue Antara Daerah Endemis Dan Daerah Sporadis. J Berk Kesehatan. 
2019;5(1):28-34.

21. Wowor R. Pengaruh Kesehatan Lingkungan terhadap Perubahan Epidemiologi Demam Berdarah di Indonesia. J e-Clinic (eCl). 2017;5(2):105-113.

22. Melangi M, Koto AG, Taslim I. Analisis Spasio-Temporal Kejadian Demam Berdarah Dengue (DBD) di Kabupaten Gorontalo (Spatio-Temporal Analysis of Dengue Health Fever (DBD) In Gorontalo District). J SAINS Inf Geogr. 2018;1(1):17-31.

23. Tahun KY, Choiruni A, Kusnanto H, IImu P, et al. Pola Spasial Temporal Demam Berdarah Dengue (DBD) Di Kecamatan Tegalrejo. J of Inform Syst for Pub Heal. 2019;4(1):80-84. 